Published in Sociology 43/6 2009: 1067-1083

\title{
Between citizenship and human rights
}

\section{Kate Nash}

\section{$\underline{\text { Abstract }}$}

This article explores the effects of the legalisation of international human rights on citizens and non-citizens within states. Adopting a sociological approach to rights it becomes clear that, even in Europe, the cosmopolitanisation of law is not necessarily resulting in greater equality and justice. In fact, 'actually existing' cosmopolitan citizenship is characterised by a proliferation of status groups that concretise new forms of inequality, including those of super-citizens, marginal citizens, quasicitizens, sub-citizens and un-citizens. Far from inaugurating a new era of genuinely universal human rights, in some cases cosmopolitan law may even contribute to the creation of conditions in which fundamental human rights are violated.

Keywords: nationalism; post-national citizenship; cosmopolitan law; migration; Europe; US

Citizenship can be described in different ways according to the emphasis that is given to its various elements. As liberals see it, citizenship is a legal status based on nationality that is conferred by a state at birth or through naturalisation and which also confers specific rights and responsibilities in relation to that state (Marshall 1992). In more republican terms, citizenship enables opportunities for political participation by means of formal procedures of voting, lobbying and standing for office or in more spontaneous ‘acts of citizenship’ and political mobilisations in civil society (Isin 2008). 
In any case citizenship also involves identity. Citizens belong to a bounded and exclusive political community with a shared history and prospective future. For the last two hundred years, the basis of the common bond between citizens has been assumed to be the nation: citizenship is experienced through belonging to a national community with shared memories, values and purposes. The individual not only gains entitlements as a citizen; she or he (usually in different ways) is also prepared to make sacrifices to the community to which s/he feels her/himself to belong (Calhoun 2007).

The close relationship between citizenship and nation has recently come under a good deal of scrutiny (eg Habermas 2001; Calhoun 2007; Kostakoupoulou 2008). Processes and discourses of globalization mean that questions of political participation which are framed in terms of the interests and values of citizens within separate and distinct nation-states are inappropriate where issues and events are not contained within national territories (Held 1995; Fraser 2005). At the same time large-scale migration and settlement in states which were previously assumed to be made up of citizens with a relatively homogeneous racial and cultural background has also called the exclusionary basis of national political community into question. Especially where minorities are resident over a long period, privileging a particular category of persons as citizens within a political community because of their skin colour and ethnicity is unjust. Do these processes of globalisation, migration and settlement mean that citizenship status, rights and identity are now becoming irrelevant? Or is citizenship itself being altered to meet the new times?

One of the most important aspects of globalisation is the development of human rights. Human rights and citizenship have long been closely entwined; indeed historically they 
share similar roots in liberal individualism. This is clearly expressed in the great eighteenth century declarations of the 'rights of man', the American and the French, which, having resoundingly called for the recognition that 'all men are created equal', born with inalienable natural rights, then go on to make it quite clear that by 'man' they mean a citizen of the national state (1). Modern states are explicitly legitimated in particularistic terms as democratically serving the national community of citizens whilst they are at the same time committed to upholding principles of universal rights. However, until relatively recently it was only political philosophers who remarked and reflected upon this paradox.

In a number of rich and thought-provoking texts, Seyla Benhabib has developed the argument that citizenship itself is now becoming cosmopolitan through developments in human rights, especially within Europe. Widespread and long-term trends of migration make this necessary: it is unjust that certain groups within a political community should be systematically treated as inferior to others on the basis of national origin (Benhabib 2004, 2007, 2008). But Benhabib argues that citizenship is actually now becoming cosmopolitan because universal human rights are no longer just moral norms; they are developing into positive law that is binding on states, especially in relation to legal and illegal immigrants. This development of human rights takes place primarily through international treaties between states, and as such it is potentially in tension with the principle of democratic self-determination that governs existing understandings of citizenship. Ulrich Beck, for example, argues that the human rights regime is self-legitimating: based not on popular consent but on the exercise of reason, human rights do not therefore need democratic deliberation and decision-making (Beck 2006: 297). Benhabib argues, however, that this tension is more imagined than real as 
what she calls the ‘democratic iteration' of cosmopolitan norms of human rights within democratic societies alters national law in conformity with universal principles of international human rights. According to Benhabib democratic iterations involve:

[C]omplex processes of public argument, deliberation, and exchange through which universalist rights claims and principles are contested and contextualized, invoked and revoked, posited and positioned throughout legal and political institutions, as well as in the associations of civil society.

Democratic iterations can take place in the "strong” public bodies of legislatives, the judiciary and the executive, as well as in the informal and “weak” publics of civil society associations and the media (Benhabib 2007: 31).

According to Benhabib, through their articulation in state and civil society democratic iterations of human rights thus create a cosmopolitan political community which finds itself to be 'not only the subject but also the author of the laws' and which includes both citizens and non-citizens (Benhabib 2007: 32). Citizenship is being 'cosmopolitanised': justice requires that rights should be extended to non-citizens who are resident within particular political communities, and this is happening, at least in Europe, with the democratic approval of the members of that community, citizens and non-citizens alike.

Benhabib’s arguments are stimulating because of the way she addresses not just the age-old problem of the relationship between universalism and particularism in political theory, but also the fact that this relationship is now changing because of the development of universal human rights within states. Human rights no longer concern 
only distant others in far off countries; they are now part of everyday political life which citizens and non-citizens negotiate within existing political communities. It is only to be expected, however, that as a political theorist, Benhabib develops her argument at a high level of abstraction. And it is only this level of abstraction that enables her to assume, as she does, that 'iterations' of human rights are actually democratic: that there is progress towards the acceptance of international human rights agreements within states and that this is contributing to cosmopolitan justice by equalising the distribution of rights and responsibilities across groups within political communities. From a sociological perspective, however, what is important is to study how the development of international human rights within states is impacting on the relationship between citizens and non-citizens in practice. Is citizenship becoming cosmopolitanised by human rights? Is there progress towards the equalisation of rights between citizens and non-citizens? Or, as we might suspect, is the picture that is emerging a good deal more complex than Benhabib’s optimistic theory would suggest?

From a sociological perspective the enjoyment of rights is never simply a matter of legal entitlement; it also depends on social structures through which power, material resources and meanings are created and circulated. To explore the relationship between citizenship and human rights, David Lockwood's work on civic stratification is a useful starting point (see Morris 2006). Lockwood argues that the actual enjoyment of rights depends on two interlinked axes of inequality: the presence or absence of legal, bureaucratic rights; and the possession of moral or material resources, which generally operate informally. The interplay of the two axes of legal entitlement and material and moral resources means that, far from abolishing gross injustice in the treatment of both citizens and non-citizens, the use of human rights is 
actually contributing to the institutionalisation of new and very complex inequalities. Legal claims that human rights activists intend to 'cosmopolitanise' states are actually tending to produce new types of formally and substantively unequal status. Indeed, in some cases securing human rights may even put people in positions in which they then find themselves subjected to further violations of their fundamental human rights.

In the following section we first consider how human rights have become legalised. Although in legal doctrine there is still an absolute dichotomy between national and international law, there is increasingly, as Benhabib argues, a 'collusion and confluence' between them in practice (Benhabib 2008: 27). As a result we are seeing the emergence of cosmopolitan law oriented towards the ideal of abolishing the distinction between the rights of citizens and those of non-citizens on which modern states were founded. In practice, however, cosmopolitan law contributes rather to the complication of citizenship as a rights-bearing status, to the concretization of new forms of inequality between citizens and non-citizens, and even to violations of human rights as such. The second section of the article analyses the paradoxical and unintended outcome of human rights advocacy in terms of a proliferation of citizenship statuses which deconstruct any absolute distinction between citizens and non-citizens, but which do not thereby inaugurate a new era of genuinely universal human rights. Finally, the concluding section considers that, if this is 'actually existing' cosmopolitan citizenship, it is as important to be aware of its inequalities, paradoxes and lacunae as it is to be optimistic about the progressive possibilities of globalisation and human rights. 


\section{Cosmopolitan law of human rights}

Human rights are becoming increasingly legalised. Although couched in legalistic language, the Universal Declaration of Human Rights was no more than a proclamation of the moral principles which should govern the activities of states with regard to individuals under their jurisdiction. Since then, however, international human rights agreements have become much more detailed and specific; they have been signed and ratified as obliging states to comply with their specifications; and they generally delegate interpretation, monitoring and implementation of those agreements to a third party (Abbott et al. 2001: 3). We can understand international human rights agreements as on a continuum from 'soft' to 'hard' law according to the degree of legalisation they encode. Most significant in terms of 'hard' law are those which delegate authority to courts for their implementation. In such cases human rights become positive law rather than just universal moral principles or political aspirations.

The legalisation of human rights transforms international law. Since the end of World War Two, international law has no longer been concerned solely with relations between states. Two major changes in international law came together then which altered it significantly. Firstly, individuals became criminally accountable for violations of the laws of war ('just obeying orders’ was no longer a legitimate legal defence, however lowly a position the accused held in the military or state hierarchy). Secondly, principles of human rights began to be developed which prescribed limits to a government's conduct towards its own citizens, to apply in times of peace as well as war (Ratner and Abrams 2001: 4; see also Held 1995: 101-2). This second principle was carried forward and extended with the Universal Declaration of Human Rights. According to the Universal Declaration of Human Rights, and the subsequent 
international human rights law that was based on it, individuals have human rights, and also the responsibility to uphold human rights, regardless of citizenship status. As Article 2 of the Universal Declaration of Human Rights has it:

'Everyone is entitled to all the rights and freedoms set forth in this Declaration, without distinction of any kind, such as race, colour, sex, language, religion, political or other opinion, national or social origin, property, birth or other status...'

However, with the partial exception of the European system of human rights, the balance of powers until the end of the Cold War meant that international law effectively maintained classic state sovereignty, being overwhelmingly concerned with keeping the peace between states (Held 2002). It is only since the Cold War that we are now seeing the beginning of cosmopolitan law, building on the 'Nuremberg principles to reach inside states and enforcing claims against human rights violators (see Held 2002; Hirsh 2003). The aim of human rights activists and legal innovators who support and extend cosmopolitan law is that each and every individual should become legally responsible for the rights of each and every other individual, regardless of their nationality and citizenship status.

Cosmopolitan law is differentially institutionalised across the world. The cosmopolitan law of human rights is especially well developed in Europe, with the European Court of Human Rights effectively acting as a 'constitutional court for civil and political rights' for all the member states of the Council of Europe (Buregnthal et al. 2002: 172). Both citizens and non-citizens have the right to bring cases to the European Court if they believe their human rights have been violated, though the 
Court only has powers to recommend to a state that it finds in violation of human rights that it should make new legislation. In addition, however, states, have bound themselves to observe the European Convention on Human Rights, and in many cases it is now part of national law. In 'monist' member states of the Council of Europe the European Convention of Human Rights is automatically the standard against which national law is judged; in 'dualist' states it may be made so by the national legislature (Smith 2007: 227-9). In the UK, for example, a dualist state, the Human Rights Act 1998 incorporated the European Convention into national law, which means that public authorities are now bound to act with respect for human rights, including judges who interpret domestic law and ministers passing legislation in government (Klug 2000).

The cosmopolitanisation of Europe is all the more striking when it is contrasted, as it often is, to the 'unilateral reassertion of sovereignty' of the US state (Benhabib 2007: 28). There are undoubtedly differences between the US and Europe in the way in which human rights have been legalised within these states. Most notably, for the most part only weak references to human rights law are possible in US courts (ie for persuasive effect, without drawing on codified US law). International treaties are not self-executing in the dualist legal system of the US. In order to become US law they must not only be signed and ratified with other contracting states, but also passed as legislation by Congress. Congress has not passed legislation to make the International Covenant on Civil and Political Rights, the civil and political rights listed in the Universal Declaration of Human Rights, into domestic law. In addition, the US is one of the few states in the world that has not ratified the International Covenant on Economic, Social and Cultural Rights, which lists in detail the social and economic 
rights that make up over half the Universal Declaration of Human Rights. It is not just, then, that the Bush Administration has been particularly opposed to the interference of the international community in US foreign and domestic affairs (whilst, of course, using the rhetoric of human rights to justify military aggression in Afghanistan and Iraq); resistance to the cosmopolitanisation of international law has been well-established for a much longer period in the political culture of the US (Ignatieff 2005).

It is important to note, however, that although human rights law is much more institutionalised in Europe than it is in the US, it is still very unevenly applied in Europe too. This is especially notable where issues of immigration and security tempt political authorities into sacrificing the rights of unpopular minorities - precisely those groups who are most in need of human rights. In fact, analysing the relationship between citizenship and human rights in Europe and the US, what is most striking in both cases is a proliferation of statuses produced out of the interplay of citizenship and human rights. The distinction between citizens and non-citizens is not abolished in this proliferation of citizenship statuses, but it does become far more complex.

\section{$\underline{\text { Citizens and mere humans }}$}

The complexity of the relationship between citizenship and non-citizenship can be analysed in terms of what I will call 'actually existing’ cosmopolitan citizenship. 'Actually existing' cosmopolitan citizenship is characterised by a proliferation of status groups. The members of each group enjoy a different package of formal and substantive rights according to their situation as citizens or non-citizens, the way in which states administer human rights, and their access to material and moral resources 
within that state. An analysis of different types of status produced with respect to the relationship between citizenship and human rights in cosmopolitan citizenship would have to include at least the following five distinctions: super-citizens, marginal citizens, quasi-citizens, sub-citizens and un-citizens.

\section{Super-citizens}

Firstly, within the legal status of 'full citizenship’ there is a marked difference between what we might call 'super-citizens' and 'marginal citizens' in relation to human rights. Super-citizens have all the rights of citizens but increasingly, in a globalising, deregulated political economy, citizenship does not tie them to states because they own the means of production or are in possession of secure employment or marketable skills which enable mobility across borders. Super-citizens are those Craig Calhoun calls ‘frequent flier’ elite cosmopolitans (Calhoun 2003).

This group has very little material interest as a group in human rights except insofar as human rights policies may succeed in making the world generally more stable and profitable. Their protected mobility comes from their citizenship status as well as from their wealth and/or skills. When faced with unstable or dangerous political conditions, super-citizens are more likely to fly home or to appeal to the authorities of the states to which they belong to intervene on their behalf than they are to claim human rights. On the other hand, they may be more likely to identify with cosmopolitanism and human rights than other people. Super-citizens may be involved in the extension of human rights as professionals - especially as lawyers, leaders of International NonGovernmental Organisations, or researchers - though they would not generally expect to see themselves as the subjects of human rights claims. With a cool detachment from 
de-moded nationalist fervour, they may also be more likely than others to celebrate specifically cosmopolitan virtues, including the adherence to principles of individual human rights (Turner 2002).

\section{Marginal citizens}

Super-citizens may be compared with a second status group, 'marginal citizens'. Marginality is conferred in two main ways on citizens who have full citizenship rights but who nevertheless do not enjoy full citizenship status: economically, by relative poverty; and socially, by racism.

Firstly, in terms of economic capacities marginal citizens are those who either do not have paid work, or who have insecure, low paid or partial participation in the labour market. This group enjoys citizenship rights to a variable degree according to different dimensions of inequality and subordination. Marginality in this sense is not, of course, new, but it is clear that the social and economic benefits of citizenship are under attack as the regulation of capitalism is altered through globalisation (see Turner 2001).

Although the growth of the global human rights regime is also an aspect of globalisation, in terms of deteriorating social citizenship, human rights are of little interest to marginal citizens. T. H. Marshall's narrative of the evolution of citizenship rights from civil, through political, to social rights to 'share in a modicum of economic welfare and security [and] to live the life of a civilised being according to the standards prevailing in the society’ is a familiar one to sociologists (Marshall 1992: 8; Nash 2000: 159-165). The Universal Declaration of Human Rights was actually developed at the high point of collectivism in the US and Europe and in negotiation with communist 
USSR and China, and it contains many articles concerning social rights. Article 22 of the UDHR, for example, which is just one of many that specify core welfare rights, states that everyone is entitled to the realisation 'through national effort and international co-operation' of their economic, social and cultural rights. However, despite their common origins in the UDHR, the history of the legalisation of human rights has been very different in the case of economic and social rights from that of civil rights.

Those who drafted the Universal Declaration of Human Rights achieved a remarkable compromise with the inclusion of the full range of civil, political and social rights that had been gained by citizens in the US and in Europe because by 1948 socialists and liberals were already engaged in bitter disputes over which should be ideologically and strategically prioritised (Forsythe 2000; Glendon 2001). This dispute continued through the Cold War, and though the political labels of the protagonists may now have changed, it continues today. One main aspect of the dispute over the validity of economic and social rights today is whether they can be legalised at all: it is hard to specify clear, detailed state obligations to meet social needs (especially where resources are lacking) in comparison with the specific obligations that must be made by specific agents to stop acting in certain ways that characterise civil rights (Donnelly 1989: 33-4; see also Dembour 2006). Making states legally accountable for making the best use of their resources to meet social and economic rights is not just logically conceivable, however: it has even been put into practice. Economic and social rights have been legalised in the South African constitution: the South African state has been called to account in its national courts for violations of the social and economic rights of people under its jurisdiction (Olivier and Jansen van Ransburg 2006). In the wealthy states of 
the global North, however, the term 'human rights' is still used almost exclusively to mean the civil rights covered by the International Covenant of Civil and Political Rights and it is these rights that are increasingly binding on states through legalisation.

Within Europe claims to economic and social human rights have been effective for some migrants within existing, deteriorating state regimes of welfare - as we shall see in the case of quasi-citizens below - but human rights language has not been developed to address issues of welfare more generally anywhere in the North. There is, for example, no provision in the system of European human rights law for economic and social rights. The European Social Charter of the Council of Europe is policy-oriented, relying on the supervision of practices through scrutiny of reports and complaints submitted to the European Committee of Social Rights, which may recommend that states should bring national law and practice into conformity with the Charter. It does not allow for adjudication in the European Court of Human Rights. Despite the apparent importance of economic and social human rights in terms of international agreements, then, they have not become cosmopolitan law in the same way as civil rights, and they do not provide protection for marginal citizens in the North. Human rights appear, rather, to be irrelevant to the welfare of these citizens.

The second way in which marginality is conferred on citizens is through racialised assumptions with regard to skin colour, ethnicity and religion. It is this aspect that is especially to the fore with heightened security during the 'war on terror' in which civil rights on which there has long been international consensus are now being ignored by powerful and influential states. A paradigm case here is that of Yasser Esam Hamdi who was imprisoned in the US without charge and without access to a lawyer for 
several years on suspicion of terrorist activities after being picked up in Afghanistan. It was at first believed that Hamdi, who was brought up in Saudi Arabia by his parents, both of whom are Saudi citizens, was not a US citizen. But even when it was confirmed that he had US citizenship as a result of being born in Louisiana, he continued to be treated as an 'enemy combatant' by the Bush Administration and to be held under similar conditions to the non-citizens in Guantanamo Bay. In 2004 Hamdi agreed to give up his US citizenship in return for deportation to Saudi Arabia (Nyer 2006). Hamdi's case was taken up by human rights organisations, but in legal terms human rights were irrelevant in this case because, as noted above, the International Covenant on Civil and Political Rights, which lawyers could certainly have used to contest his arbitrary detention, is not incorporated into domestic law in the US. Human rights organisations could only draw public attention to the Bush Administration's violations of international human rights; in court they could use only US law. In addition, however, Hamdi’s citizenship status, though not completely irrelevant (it did save him from the status of 'un-citizen', and from incarceration in Guantanamo), also proved to be of so little value to him that he was relatively easily persuaded to give it up. Hamdi was never charged nor tried in a US court. (2)

Although the specifics of these US cases are distinctive, the status of racialised 'marginal citizenship' is by no means confined to the US. A good European comparison with Hamdi's case is that of French citizens awaiting charges in French prisons while suspicions of their involvement in terrorist activities are investigated sometimes for years (Human Rights Watch Report 2008). Whilst the procedures to investigate suspected criminal activities in France do not formally distinguish between Muslims and non-Muslims, or indeed between suspected terrorists and other suspected 
criminals, there is no doubt that Muslims suspected of terrorism are far more likely to suffer the abuses for which the system has been criticised more generally. Human rights are not irrelevant in the same way in such cases as they were in the Hamdi case: indeed, the French state has been regularly criticised for its criminal procedures by the European Court of Human Rights, including on grounds of torture (the only country other than Turkey to have such a finding against it by the court). They are irrelevant, however, because the French government and judiciary have ignored proposals for reform of the system - even when they have come from a commission set up by the French state itself to investigate the legality of these procedures with respect to human rights law (Hodgson 2004: 189). This disregard for human rights clearly opens up the possibility that some citizens, especially those suspected of the most serious crimes against the state, will be treated quite differently from others.

\section{Quasi-citizens}

Thirdly, there are 'quasi-citizens' who are in a different legal position from either super or marginal citizens. Quasi-citizens are denizens, or long-term residents in a state who have access to employment and who have gained rights similar to citizens as a result of relatively secure employment, long-term residence and political mobilisation. They have successfully organised politically to put pressure on states to recognise their human rights in order to gain access to education, health-care, housing and other welfare rights on the same basis as citizens, as well as cultural rights to translators in welfare services, some education for children in the language of their homeland and so on. Quasi-citizens do not, however, have political rights to vote in the national elections of states in which they are resident, though in some cases they have rights to vote in local and European elections (Balibar 2004; Benhabib 2008). 
The category of quasi-citizens contains a diverse group of people. In Europe it includes some EU citizens - those from less powerful states who are employed in unskilled work - and guest-workers who, often with their families, have sometimes been resident as non-nationals, and therefore as non-EU citizens too, for generations (Morris 2002). In the US, it also includes settled communities of migrant workers who have won social rights to health-care, education for children, housing and other welfare rights though they have not naturalised as citizens. They have won these rights under the US constitution rather than through human rights advocacy but, according to David Jacobson, social rights constitute a substantial material gain for non-citizens in the US (Jacobson 1996). The category also includes political refugees who have been granted asylum as a result of international commitments signed and administered by states in accordance with human rights principles who may similarly be resident as nonnationals for many years.

Whilst, as Soysal (1994) has argued, what she calls ‘postnational citizenship’ has been an important advance for migrants in terms of institutionalising their human rights, the relative instability of their legal status (as they are 'not-citizens') and the dangers it creates for securing other fundamental human rights on which they may need to depend is becoming clearer. A good example of the dangers of quasi-citizenship in this respect comes from the UK state's treatment of political refugees who were arrested and detained without charge on suspicion of terrorist activities following 9/11. The 'Belmarsh detainees' were held for up to three years before the Law Lords, the highest court of appeal in the UK, found their imprisonment unlawful on the grounds of discrimination against non-citizens, a ruling based on the European Convention of 
Human Rights. However, in response to the Lords’ ruling, parliament passed the Prevention of Terrorism Act in 2005 which granted the Executive the power to keep suspected terrorists under 'control orders' if the authorities had 'reasonable suspicion' about their activities based on secret evidence (which neither they nor their lawyers were allowed to see). The Prevention of Terrorism Act put an end to discrimination against non-citizens by sanctioning the violation of the fundamental rights of citizens too: all are potentially equally subject to a range of punitive measures without ever having been charged with a crime or having had the chance to defend themselves in court. Again it is clear from this example that, although the rule of law may be formally upheld in such legislation, some people are far more likely to be subject to punitive measures than others. In this case it is those who have been granted refugee status (in order to safeguard their human rights) who then find themselves at risk of arbitrary detention (in violation of fundamental human rights) (see Nash 2009).

Furthermore, as a result of the Law Lords ruling, the UK government went still further in attempting to deal with refugees they suspected of having connections with terrorists, proposing to send them back to their countries of origin on the proviso that the authorities there promised to guarantee their safety. This is absolutely forbidden by the Convention Against Torture, incorporated into UK law in the Criminal Justice Act 1988, and so far it has not been allowed by the UK’s highest court. Similarly, the US also tried to deport a refugee, Sameh Khouzam, on the basis of 'diplomatic assurances' from Egypt that state agents would not torture or kill him if he were sent back. It was not permitted by the US courts because the Convention Against Torture is one of the rare international human rights instruments that has been incorporated into US law, and 
it forbids the government to transfer a person to a state where there are reasons to be believe they will be subjected to torture.

What we see, then, in relation to the status of quasi-citizenship is that state action has been limited in conformity with human rights law in cases of arbitrary detention, torture and murder, both in Europe and the US. The legalisation of human rights has effectively resulted in cosmopolitan law in such cases, equalising the legal status of citizens and non-citizens alike. On the other hand, however, quasi-citizens find themselves in a position where, although their human rights are protected in some respects, they are at the same time threatened by the very states that protect them. In terms of moral resources, their status is far less than that of full citizens and this affords them less protection than citizens. What is as striking as the legal deconstruction of the distinction between citizens and non-citizens in these cases is the determination of the US and UK governments to violate the human rights of quasi-citizens in the name of national security. It is clear that in the case of the legislation enabling the imprisonment of the 'Belmarsh detainees' the UK government made a political calculation that it would not be able to detain British citizens indefinitely without charge, even if those citizens potentially pose as great a security threat as non-citizens. The position of quasi-citizens is precarious because their status is secured only by human rights which, though they may be effective, eventually, in the legal domain, are insufficient to achieve the degree of respect to which citizens in general are supposed to be legitimately entitled.

\section{Sub-citizens}


If quasi-citizens are in a precarious position with regard to their fundamental human rights, sub-citizens routinely face even greater difficulties. Sub-citizens are those who do not have paid employment in the country in which they are resident, nor any entitlement to state benefits there. In both Europe and the US this category includes those who are waiting to have asylum cases heard and who may be detained indefinitely in camps whilst that process is going on. It also includes those considered to be adult dependants of quasi-citizens - wives and other family members - who have no independent right to residence and who are, therefore, potentially subject to violence and abuse within the home (without real possibility of redress), as well from their home states.

Such legal status as ‘sub-citizens' enjoy is literally created by international human rights law as it is administered through state-specific policies. The status of refugees in the country in which they are detained or resident is based on international law concerning the human rights of refugees, derived from the 1951 UN Convention Relating to the Status of Refugees, and on national regulations concerning the administration of that law. Sub-citizens who are the dependants of quasi-citizens have virtually no legal status in international law as individuals, but only that which has been won through national political mobilisation, usually by women’s groups. In the UK, for example, it was as a result of such campaigning that the government finally lifted the rule which meant that a wife could not leave a husband who abused her during their first year of residence without being immediately removed from the country - though the type of evidence of abuse that is admitted in these cases is still unacceptably restricted ('Campaigns’ www.southallblacksisters.org.uk, consulted 27 November 2007). 


\section{Un-citizens}

Finally, even sub-citizens are in a better position than un-citizens. This group includes undocumented migrants who have no recognised status in receiving countries and who may be detained in refugee camps or immediately deported if they are not permitted to apply for asylum, even if they have been living and working there for years. It also now includes people detained in the 'war on terror' in newly created 'non-places' which are outside national territories and therefore somehow also outside the jurisdiction of sovereign states, whilst nevertheless being under their administration.

The most famous example here is Guantanamo Bay, though there are also other such camps containing suspected terrorists in Bagram, Kandahar and elsewhere. These uncitizens are in a legal 'black hole' because of the special status they have been assigned as 'illegal combatants' and the extraordinary lengths to which the US executive has gone to deny them access to lawyers and to keep them out of US courts (Steyn 2004). This is not to say that Guantanamo Bay falls outside the law; on the contrary it is rather that in anticipation of, and in response to, legal challenges on the basis of international and US law the camp has been created precisely in the complex interstices of international and national law (Johns 2005; Nash 2009).

Guantanamo Bay is the most visible symbol of the lack of human rights in the US. There is no legal recourse to international human rights which would cut through the legal obfuscations out of which it has been created, though politically it is human rights organisations that have been largely responsible for monitoring and publicising the situation of the detainees there. They are also responsible for bringing cases to the US 
courts using national law. Indeed, the Supreme Court has twice now ruled that it is unconstitutional to deny the Guantanamo Bay detainees habeus corpus rights to challenge the legality of their detention in court. In the first case, Rasul v. Bush 2004, the ruling was relatively weak, stating only that detainees have formal rights to procedures by which to challenge their detention. It resulted in the Military Commissions Act of 2006 in which detainees were granted access to military courts that fell well short of normal legal procedures. The second ruling in 2008 was far stronger, stating that detainees must have recourse to civilian courts. This has not yet resulted in action at the time of writing. Though the closure of Guantanamo Bay is widely predicted, indeed it was one of the election promises of incoming US President Barak Obama, the fate of the remaining detainees is far from certain.

\section{‘Actually existing' cosmopolitan citizenship}

Human rights law is supposed to equalise the status of citizens and non-citizens within and across states, at least along some significant dimensions. In the case of civil rights, often called fundamental rights in the US and Europe, rights to equality before the law and to personal and political freedom are very well-established at the international level and in the rhetoric of state legitimation abroad and at home. In the case of economic and social rights the requirements on states are far less clear - certainly neither the Universal Declaration of Human Rights nor the International Covenant on Economic, Social and Cultural Rights stipulates anything like formal equality between citizens or between citizens and non-citizens. There is, however, a requirement on states to meet the basic needs of people under their jurisdiction, citizens or not, and to co-operate internationally to meet the basic needs of people in other states too. 
What we see, however, as a result of the uneven application of human rights law combined with existing social and economic inequalities amongst citizens and noncitizens, is a proliferation of statuses regarding citizenship and human rights rather than an equalisation of treatment for citizens and non-citizens. 'Actually existing' cosmopolitanism involves the multiplication of differences which are also inequalities: packages of rights that are adapted to time and place, to the particular configurations of citizens and non-citizens who happen to find themselves living under a particular jurisdiction in particular political circumstances. Politicians seek re-election rather than the protection of minority rights; judges are very rarely trained in human rights law (none of the judges involved in the Law Lords' cases concerning the Belmarsh detainees, for example, is an expert on human rights); and the media tend to frame human rights concerns in terms of national interests (Nash 2009). Under such circumstances it is extremely difficult to create the political will to secure the equality of citizens and non-citizens, cosmopolitan law is slow, extraordinarily complex and multi-layered, and - even where it can be used - difficult and politically controversial to apply. Human rights for non-citizens are far from popular. The result is that in practice there are quite different sets of rights for different persons of different status.

Although there is no equalisation between citizens and non-citizens as a result of the cosmopolitanisation of human rights law, then, the proliferation of citizenship statuses in relation to human rights does result in a breakdown of the absolute distinction between citizen and non-citizen on which the nation-state was founded. This is especially evident in Europe in comparison with the US, though to some extent it is happening there too, largely thanks to the activities of human rights organisations and despite the limited legal resources with which they have to work. It is very important 
not to idealise Europe in comparison with the US: racialised minorities continue to be very unpopular in both places, especially in the ongoing conditions of heightened national security, and this affects how human rights are interpreted and implemented even where human rights law is relatively well-established.

Human rights play an ambiguous role in the new political regime. On the one hand the way in which human rights are currently being interpreted in legal terms accommodates inequalities: human rights give little purchase on structures of social and economic inequity; and they are not easily articulated as part of an anti-racist strategy to address the targeting of some groups as so dangerous that their rights must be curtailed for the good of all. Furthermore, the legalisation of human rights seems to make comparison across statuses difficult: even where the fundamental rights of non-citizens are respected, these groups do not enjoy the same legal and moral status as citizens. In contrast the formal and substantive equality of national citizenship was an aspiration, even if it has never been close to full realisation. On the other hand human rights are being used by organisations to frame and contest inequalities in the treatment of citizens and non-citizens as violating human rights. In this respect human rights do function as an ideal to aspire to: the remedy for human rights abuses is more and better human rights law, better education for the judiciary and for politicians, more effective mobilisation by advocacy organisations, a more responsible media and so on. The difficulty for us, caught up in what appears to be the dismantling of the ideal of the national state and the emergence of 'actually existing' cosmopolitanism, is how to assess the potential of human rights for justice. Are human rights a progressive force, tending in the main to articulate clear ideals of cosmopolitan justice around which it is possible to mobilise to fight injustice? Or have human rights themselves become part 
of the problem, lending legitimacy to differences which are actually new forms of inequality and which may even solidify into opportunities for the state's ill-treatment and abuse of individuals which human rights law was supposed to end?

\section{Notes}

1. This is especially, and notoriously, evident in the formulation of the French Declaration of the Rights of Man.

Article 1. Men are born and remain free and equal in rights. Social distinctions may be founded only upon the general good.

Article 2. The aim of all political association is the preservation of the natural and imprescriptible rights of man. These rights are liberty, property, security, and resistance to oppression.

Article 3. The principle of all sovereignty resides essentially in the nation.

We move very rapidly here from abstract statements of the universal rights of man, to an assertion of the sovereignty of the nation, which is empowered to make such social distinctions as are deemed necessary for the good of all. The move from universal to particular is perhaps less obvious in the wording of the American Declaration of Independence, which begins: 'We hold these truths to be self-evident, that all men are created equal, that they are endowed by their Creator with certain unalienable Rights, that among these are Life, Liberty and the pursuit of Happiness.' What is important here is the 'we', which - though it is not specified - is that of the American nation. The American Declaration presupposes rather than explicitly states that it is 
individuals who are members of the nation who are in possession of the universal rights of man.

2. The comparable, if less dramatic, case is that of Jose Padilla, also a US citizen and also treated as an 'enemy combatant' by the Bush Administration. It was only after several years in prison and as a result of pressure from civil liberties groups which took his case all the way to the Supreme Court, that Padilla was charged. Tried in a civilian court, he was found guilty of criminal conspiracy and sentenced to 17 and a half years in jail.

\section{References}

Abbott, K. and Snidal, D. (2001), 'Hard and Soft Law in International Governance’, in J. Goldstein, M. Kahler, R. Keohane, R. and A-M Slaughter (eds) Legalization and World Politics, Cambridge, Massachusetts: MIT Press.

Balibar, E. (2004) We, the People of Europe? Reflections on Transnational Citizenship Princeton: Princeton University Press.

Beck, U. (2006) Power in the Global Age, Cambridge: Polity.

Benhabib, S. (2004), The Rights of Others: Aliens, Residents and Citizens, Cambridge: Cambridge University Press.

Benhabib, S. (2007) 'Twilight of Sovereignty or the Emergence of Cosmopolitan Norms? Rethinking Citizenship in Volatile Times’ Citizenship Studies 11/1:19-36

Benhabib, S. (2008) Another Cosmopolitanism Oxford: Oxford University Press.

Burgenthal, T, Shelton, D and Stewart, D. (2002) International Human Rights St Paul, Minnesota: West Publishing Co. 
Calhoun, C. (2003) 'The Class Consciousness of Frequent Travellers: Towards a Critique of Actually Existing Cosmopolitanism’ in D. Archibugi (ed) Debating Cosmopolitics. London: Verso.

Calhoun, C. (2007), Nations Matter: Culture, History and the Cosmopolitan Dream, London and New York: Routledge.

Dembour, M. (2006) Who Believes in Human Rights? Reflections on the European Convention Cambridge: Cambridge University Press.

Donnelly, J. (1989) Universal Human Rights in Theory and Practice, Ithaca, New York: Cornell University Press.

Forsythe, D. (2002) Human Rights in International Relations Cambridge: Cambridge University Press.

Fraser, N. (2005), 'Reframing Justice in a Globalizing World', New Left Review 36:

69-88.

Glendon, M. (2001) A World Made New: Eleanor Roosevelt and the Universal Declaration of Human Rights New York: Random House.

Habermas, J. (2001), The Postnational Constellation, Cambridge: Polity.

Held, D. (1995) Democracy and the Global Order: from the Modern State to Cosmopolitan Governance Cambridge: Polity Press.

Held, D. (2002), 'Law of States, Law of Peoples: Three Models of Sovereignty' Legal Theory 8/1: 1-44.

Hirsh, D. (2003), Law against Genocide: Cosmopolitan Trials, London: Glasshouse Press.

Hodgson, J. (2004) 'Human Rights and French Criminal Justice: Opening the Door to Pre-Trial Defence Rights’ in S. Halliday and P. Schmidt (eds) Human Rights Brought 
Home: Socio-Legal Perspectives on Human Rights in the National Context Oxford and Portland: Hart.

Human Rights Watch (2008) 'Preempting Justice: Counterterrorism Laws and

Procedures in France’ New York: Human Rights Watch.

Ignatieff, M. (2005), (ed) American Exceptionalism and Human Rights Princeton:

Princeton University Press.

Isin, E. (2008) ‘Theorizing Acts of Citizenship’ in E. Isin and G. Nielson (eds) Acts of Citizenship London: Zed Books.

Jacobson, D. (1996) Rights Across Borders: Immigration and the Decline of Citizenship

Baltimore: Johns Hopkins University Press.

Johns, F. (2005), 'Guantanamo Bay and the Annihilation of the Exception’ in The European Journal of International Law 16/4: 613-35.

Kostakopoulou, D. (2008) The Future Governance of Citizenship Cambridge:

Cambridge University Press.

Klug, F. (2000), Values for a Godless Age: the Story of the UK's New Bill of Rights, London: Penguin.

Marshall, T. H. (1992) Citizenship and Social Class, ed. T. Bottomore. London: Pluto Press.

Morris, L. (2002) Managing Migration: Civic Stratification and Migrant Rights

London: Routledge.

Morris, L. (2006) 'Sociology and rights - an emergent field’ in L. Morris (ed) Rights:

Sociological Perspectives London: Routledge

Nash, K (2000), Contemporary Political Sociology: globalization, politics and power, Oxford:

Blackwell 
Nash, K. (2009) The Cultural Politics of Human Rights: Comparing the US and UK Cambridge: Cambridge University Press.

Nyer, P. (2006), ‘The accidental citizen: acts of sovereignty and (un)making citizenship’ in Economy and Society 35/1: 22-41.

Olivier, M. and Jansen van Rensburg, L. (2006) 'South African poverty law: the role and influence of international human rights instruments’ in L. Williams (ed) International Poverty Law: an emerging discourse London: Zed Books.

Ratner, S. and J. Abrams (2001) Accountability for Human Rights Atrocities in International Law: Beyond the Nuremberg Legacy Oxford: Oxford University Press. Smith, R. (2007) Texts and Materials on International Human Rights London: Routledge-Cavendish.

Soysal, Y. (1994) Limits of Citizenship: Migrants and Postnational Membership in Europe Chicago: University of Chicago

Steyn, J (2004) ‘Guantanamo Bay: The legal black hole’ International and Comparative Law Quarterly, 53/1: 1-15

Turner, B. (2001) ‘The erosion of citizenship’ British Journal of Sociology 52/2: 189209

Turner, B. (2002) ‘Cosmopolitan virtue, globalization and patriotism’ Theory, Culture and Society, 19/1-2: 45-63 